\title{
PENGARUH KECERDASAN EMOSIONAL DAN GAYA KEPEMIMPINAN TRANSFORMASIONAL TERHADAP KINERJA GURU SMA NEGERI DI KECAMATAN KALIDERES JAKARTA BARAT
}

\author{
Mohamad Rafdi Zhafari \\ Universitas Islam Negeri Syarif Hidayatullah Jakarta \\ rafdiii26@gmail.com \\ Hemmy Fauzan \\ Universitas Islam Negeri Syarif Hidayatullah Jakarta \\ fauzan.hemmy@gmail.com \\ Nofrianto \\ nofrianto@uinjkt.ac.id \\ Universitas Islam Negeri Syarif Hidayatullah Jakarta
}

\begin{abstract}
This study aims to research the influence of emotional intelligence and tranformational leadership style and simultaneously on teacher performance. The data used in this study are primary and secondary data obtained from the field and library data. The sample in this study were 123 teacher of SMA Negeri in Kalideres. By using simple random sampling method. This type of research is quantitative. The analysis performed is multiple linear regression using SPSS 22. The results of this study indicate that emotional intelligence and tranformational leadership style and simultaneously have a significant effect on the performance teacher of SMA Negeri in Kalideres.
\end{abstract}

Keywords: Emotional intelligence and tranformational leadership style, Employee performance.

\begin{abstract}
Abstrak
Penelitian ini bertujuan untuk mengetahui pengaruh kecerdasan emosional dan gaya kepemimpinan transformasional secara parsial maupun simultan terhadap kinerja guru. Data yang digunakan dalam penelitian ini adalah data primer dan sekunder yang diperoleh dari lapangan dan data pustaka. Sampel pada penelitian ini adalah 123 orang guru SMA Negeri Se-Kecamatan Kalideres. Dengan menggunakan metode sampel simple random sampling. Jenis penelitian ini adalah kuantitatif. Metode analisis yang digunakan adalah analisis regresi linier berganda dengan menggunakan SPSS 22. Hasil penelitian ini menunjukan pengaruh kecerdasan emosional dan gaya kepemimpinan transformasional secara parsial maupun simultan mempunyai pengaruh signifikan terhadap kinerja guru di SMA Negeri di Kecamatan Kalideres.
\end{abstract}

Nur El-Islam, Volume 7, Nomor 1, April 2020 
Kata kunci: pengaruh kecerdasan emosional dan gaya kepemimpinan transformasional, kinerja guru.

\section{PENDAHULUAN}

Pendidikan merupakan salah satu keperluan dasar yang harus dimiliki setiap manusia. Untuk menambah kualitas sumber daya manusia agar tercapainya tingkat kehidupan yang semakin makmur dan sejahtera. Penyelenggaraan pendidikan di Indonesia sendiri menerapkan sistem pendidikan nasional yang diatur secara sistematis. Pendidikan nasional berfungsi mengembangkan kemampuan dan membentuk watak serta peradaban bangsa yang bermartabat dalam rangka mencerdaskan kehidupan bangsa, bertujuan untuk berkembangnya potensi peserta didik agar menjadi manusia yang beriman dan bertakwa kepada Tuhan Yang Maha Esa, berakhlak mulia, sehat, berilmu, cakap, kreatif, mandiri, dan menjadi warga negara yang demokratis serta bertanggung jawab (UU No. 20 Tahun 2003).

Di indonesia sendiri, sektor pendidikan masih memiliki beberapa permasalahan yang belom terselesaikan hingga kini dengan berbagai macam problematika. Berdasarkan Education Index yang dikeluarkan oleh Human Development Reports, pada 2017, Indonesia ada di posisi ke tujuh di ASEAN dengan skor 0,622. Skor tertinggi diraih Singapura, yaitu sebesar 0,832 . Peringkat kedua ditempati oleh Malaysia $(0,719)$ dan disusul oleh Brunei Darussalam $(0,704)$. Pada posisi keempat ada Thailand dan Filipina, Keduanya sama-sama memiliki skor 0,661. Angka tersebut dihitung dengan menggunakan Mean Years of Schooling dan Expected Years of Schoolin. Hal ini masih menggambarkan betapa rendahnya kualitas pendidikan yang ada di Indonesia ${ }^{1}$.

Kinerja guru memiliki elemen yang penting dalam majunya sektor sumber daya manusia di Indonesia dengan berbagai pendidikan yang diberikan. Sementara itu, dalam menjalankan tugasnya seorang guru harus memiliki empat kompetensi, yakni kompetensi dasar seperti pedagogik, profesional, kepribadian, dan sosial. Keempat

\footnotetext{
${ }^{1}$ https://tirto.id/pendidikan,2017
} 
kompetensi ini masih belum banyak terlihat ada semuanya di figur dari seorang guru yang ada di Indonesia ${ }^{2}$.

Diantara berbagai faktor yang mempengaruhi suatu kinerja, pada peradaban ini Kecerdasan emosional merupakan salah satu yang mempunyai pengaruh terhadap kinerja. Perkembangan zaman dengan berkembangnya teknologi dan hadirnya globalisasi menciptakan pemikiran yang berbeda mengenai suatu pekerjaan dalam organisasi. Memiliki kecerdasan emosional merupakan salah satu indikator yang harus dimiliki setiap manusia terutama bagi seorang guru dalam instansi pendidikan.

Kinerja guru outputnya sangat ditentukan oleh faktor psikologis guru tersebut yaitu kecerdasan emosional. Berdasarkan realita di lapangan menunjukkan, seorang guru yang mempunyai kecerdasan intelektual tinggi tidak menjamin keberhasilan dalam pembelajarannya, namun seorang guru yang kecerdasan intelektualnya nya sedang tetapi kecerdasan emosionalnya tinggi lebih besar peluang keberhasilannya dalam kegiatan pembelajaran. Kinerja karyawan/guru ini akan mempengaruhi keseluruhan organisasi, dan karenanya, jika seseorang memiliki kecerdasan emosional yang tinggi mereka akan melakukan pekerjaan mereka dengan baik dan mereka akan bekerja secara efektif dengan cara yang utama dengan menangani emosi mereka sendiri ${ }^{3}$

Pada penelitian kali ini akan mengangkat permasalahan yang ada di SMA Negeri yang ada di Kecamatan Kalideres. Sebagai suatu organisasi, sekolah tidak bisa lepas dari tuntutan kerja yang maksimal... Pada tahap ini kecerdasan emosional merupakan salah satu indikator yang penting yang harus dimiliki oleh setiap guru. Selain itu gaya kepemimpinan transformasional haruslah dimiliki oleh seorang pemimpin dari suatu organisasi termasuk sekolah. Kepala sekolah sebagai pemimpin dituntut memiliki gaya kepemimpinan yang transformasional, karena kemampuan untuk membimbing,

${ }^{2}$ https:/www.republika.co.id/berita/pendidikan,

${ }^{3}$ Radha, B., \& Arepalli, B. S. "Impact of Emotional Intelligence on Performance of Employees at Manufacturing Organizations”. International Journal of Recent Technology and Engineering, 8(3), 570-572. (2019) 
mempengaruhi dan memimpin warga sekolah untuk mencapai destinasi dari visi dan misi sekolah haruslah tercapai.

Peneliti sendiri telah melakukan wawancara dengan guru-guru di SMA Negeri di Kecamatan Kalideres terkait masalah kecerdasan emosional dan dari hasil wawancara ini memiliki permasalahan tersendiri bagi para guru. Setiap sekolah yang peneliti datangi, peneliti masing-masing melakukan wawancara dengan 7 guru pada 4 sekolah, sehingga secara keseluruhan peneliti telah melakukan wawancara dengan 28 guru terkait fenomena-fenomena yang terjadi di lingkungan sekolah mengenai kecerdasan emosional.

\begin{tabular}{|c|c|c|c|c|c|c|c|}
\hline \multirow{3}{*}{ No } & \multirow{3}{*}{ Sekolah } & \multicolumn{6}{|c|}{ Permasalahan Terkait Kecerdasan Emosional } \\
\hline & & \multicolumn{2}{|c|}{ Mengelola Emosi Diri } & \multicolumn{2}{|c|}{$\begin{array}{l}\text { Social Skills } \\
\text { (Keterampilan Sosial) }\end{array}$} & \multicolumn{2}{|c|}{$\begin{array}{l}\text { Mengenali Emosi Orang } \\
\text { Lain }\end{array}$} \\
\hline & & Jumlah & Presentase & Jumlah & Presentase & Jumlah & Presentase \\
\hline 1. & SMAN 84 & 3 & $42,85 \%$ & 2 & $28,57 \%$ & 2 & $28,57 \%$ \\
\hline 2. & SMAN 95 & 2 & $28,57 \%$ & 3 & $42,85 \%$ & 2 & $28,45 \%$ \\
\hline 3 & SMAN 56 & 2 & $28,57 \%$ & 4 & $57,14 \%$ & 1 & $14,28 \%$ \\
\hline 4 & SMAN 94 & 4 & $57,14 \%$ & 2 & $28,57 \%$ & 1 & $14,28 \%$ \\
\hline & Total & 11 & $39,28 \%$ & 11 & $39,28 \%$ & 6 & $21,42 \%$ \\
\hline
\end{tabular}

Berdasarkan tabel 1.1, narasumber mengemukakan bahwa permasalahan yang terjadi terkait kecerdasan emosional yang terjadi di SMA Negeri se-Kecamatan Kalideres mengenai mengelola emosi diri, social skills (keterampilan sosial) dan mengenali emosi orang lain. Pada hasil wawancara tersebut adalah dominan pada proses mengelola emosi diri dan keterampilan sosial dengan presentase masing-masing indikator yaitu 39,28\%.

Kinerja guru dipengaruhi oleh beberapa faktor lainnya seperti gaya kepemimpinan. Problematika terkait kepemimpinan menjadi masalah bagi setiap organisasi terutama dalam instansi pendidikan, kepemimpinan memiliki peran sentral dalam berjalannya kinerja suatu organisasi dan dalam menciptakan kebijakan yang berkemajuan.

Pada tahap ini, tipe gaya kepemimpinan transformasional mulai mengemuka seiring dengan berkembangnya zaman dan perubahan 
sifat secara individual yang lebih visioner, dalam kasus kepemimpinan khususnya gaya kepemimpinan transformasional telah diidentifikasi sebagai pendekatan yang sangat berbeda. Pemimpin mengisyaratkan para bawahannya untuk mendukung dalam perubahan organisasi sehingga terjadi adanya potensi perubahan organisasi kinerja kearah yang lebih baik dan produktif ${ }^{4}$.

\begin{tabular}{|c|c|c|c|c|c|c|c|}
\hline \multirow{3}{*}{ No } & \multirow{3}{*}{ Instansi } & \multirow{3}{*}{ Bulan } & \multirow{3}{*}{$\begin{array}{l}\text { Jumlah } \\
\text { Guru }\end{array}$} & \multicolumn{4}{|c|}{ Tingkat Absensi } \\
\hline & & & & \multicolumn{2}{|c|}{ Tidak Hadir } & \multicolumn{2}{|c|}{ Terlambat } \\
\hline & & & & Jumlah & Presentase & Jumlah & Presentase \\
\hline \multirow[t]{4}{*}{1} & \multirow[t]{4}{*}{ SMAN 84} & Maret & 48 & 9 & $18,75 \%$ & 12 & $25 \%$ \\
\hline & & April & 48 & 11 & $22,91 \%$ & 16 & $33,33 \%$ \\
\hline & & Mei & 48 & 8 & $16,66 \%$ & 15 & $31,25 \%$ \\
\hline & & Juni & 48 & 9 & $18,75 \%$ & 14 & $29,16 \%$ \\
\hline \multirow[t]{4}{*}{2} & \multirow[t]{4}{*}{ SMAN 95} & Maret & 56 & 12 & $21,42 \%$ & 19 & $33,92 \%$ \\
\hline & & April & 56 & 14 & $25 \%$ & 20 & $35,71 \%$ \\
\hline & & Mei & 56 & 10 & $17,85 \%$ & 18 & $32,14 \%$ \\
\hline & & Juni & 56 & 15 & $26,78 \%$ & 22 & $39,28 \%$ \\
\hline \multirow[t]{4}{*}{3} & \multirow[t]{4}{*}{ SMAN 56} & Maret & 38 & 4 & $10,52 \%$ & 15 & $39,47 \%$ \\
\hline & & April & 38 & 8 & $21,05 \%$ & 12 & $31,57 \%$ \\
\hline & & Mei & 38 & 6 & $15,78 \%$ & 16 & $42,10 \%$ \\
\hline & & Juni & 38 & 6 & $15,78 \%$ & 13 & $34,21 \%$ \\
\hline \multirow[t]{4}{*}{4} & \multirow[t]{4}{*}{ SMAN 94} & Maret & 35 & 5 & $14,28 \%$ & 8 & $22,85 \%$ \\
\hline & & April & 35 & 7 & $20 \%$ & 14 & $40 \%$ \\
\hline & & Mei & 35 & 7 & $20 \%$ & 11 & $31,42 \%$ \\
\hline & & Juni & 35 & 5 & $14,28 \%$ & 10 & $28,57 \%$ \\
\hline
\end{tabular}

Berdasarkan tabel diatas maka dapat terlihat mengenai absensi kehadiran dari para guru pada periode Maret-Juni. Data mengenai keterlambatan dan kehadiran yang terjadi selama 4 bulan tersebut mengalami fluktuatif dan cenderung turun naik pada bulan selanjutnya.Naiknya absensi ketidakhadiran tersebut mengindikasikan lemahnya gaya kepemimpinan transformasional yang diterapkan oleh pimpinan sekolah tersebut. Hal ini tekait kurangnya Motivasi inspirasional (inspirational motivation), konsiderasi individual (individualized considerations), Idealis (idealized influence). Pemimpin seharusnya ikut terlibat dengan memberikan perhatian dengan masalah absensi tersebut. kepemimpinan transformasional itu sendiri adalah seperti hubungan dimana pemimpin mampu mendorong bawahan untuk turut serta dalam memberikan yang terbaik di

${ }^{4}$ Pradhan,S., \& Pradhan, R. K. “An Empirical Investigation Of Relationship Introduction". (2015) 
organisasi untuk menghasilkan tingkat kinerja yang tinggi dan terjalinnya hubungan yang baik antara pemimpin dan pengikut ${ }^{5}$

\section{TINJAUAN TEORITIS}

\section{Manajemen}

Manajemen berasal dari bahasa Inggris "to manage" yang berarti mengelola suatu aktivitas untuk mencapai tujuan yang telah ditentukan. Menurut G.R Terry ${ }^{6}$ menyatakan bahwa pengertian Manajemen adalah suatu proses khas yang terdiri atas tindakantindakan perencanaan, pengorganisasian, pergerakan dan pengendalian untuk menentukan serta mencapai tujuan melalui pemanfaatan sumber daya manusia dan sumber daya lainnya".

Sedangkan pengertian Manajemen menurut Malayu S.P Hasibuan $^{7}$ mengemukakan bahwa "manajemen adalah ilmu dan seni mengatur proses pemanfaatan sumber daya manusia dan sumber lainnya secara efektif dan efisien untuk mencapai suatu tujuan tertentu”.

Sedangkan Menurut Abdullah ${ }^{8}$ manajemen itu adalah keseluruhan aktivitas yang berkenaan dengan melaksanakan pekerjaan organisasi melalui fungsi-fungsi perencanaan,pengorganisasian, pengarahan dan pengawasan untuk mencapai tujuan organisasi yang sudah ditetapkan dengan bantuan sumber daya organisasi (man, money, method, machine and material) secara efektif dan efisien.

${ }^{5}$ Advani, A., \& Abbas, Z. "Impact of Transformational and Transactional Leadership Styles on Employees' Performance of Banking Sector in Pakistan ". Global Journal of Management and Business Research, (2015).

${ }^{6}$ Terry, George dan Leslie W. Rue. “Dasar-dasar Manajemen”, Cetakan kesebelas, PT Bumi Aksara, Jakarta. (2010).

${ }^{7}$ Hasibuan, Malayu S.P. “Manajemen Sumber Daya manusia”. Edisi Revisi. Jakarta: Penerbit Salemba Empat, (2016)

${ }^{8}$ Abdullah,M. "Manajemen dan Evaluasi Kinerja Karyawan". Aswaja Presindo, Yogyakarta. (2014) 


\section{Manajemen Sumberdaya Manusia}

Menurut Edison ${ }^{9}$ mengemukakan mengenai manajemen sumber daya manusia yaitu: "Manajemen yang memfokuskan diri memaksimalkan kemampuan karyawan atau anggotanya melalui berbagai langkah strategis dalam rangka meningkatkan kinerja pegawai/karyawan menuju pengoptimalan tujuan organisasi.”

Sedangkan menurut Menurut Dessler ${ }^{10}$, manajemen sumber daya manusia adalah proses untuk memperoleh, melatih, menilai, dan mengompensasi karyawan dan untuk mengurus relasi tenaga kerja, kesehatan dan keselamatan, serta hal-hal yang berhubungan dengan keadilan.

Menurut Hasibuan ${ }^{11}$ pengertian manajemen sumber daya manusia (MSDM) adalah ilmu dan seni mengatur hubungan dan peranan tenaga kerja agar efektif dan efisien membantu terwujudnya tujuan perusahaan, karyawan dan masyarakat.

\section{Kecerdasan Emosional}

Istilah kecerdasan emosional baru dikenal secara luas pertengahan 90-an dengan diterbitkannya buku Daniel Goleman Emotinal Intelligence. Menurut Goleman ${ }^{12}$ yang menyatakan bahwa kecerdasan emosional adalah kemampuan seseorang mengatur kehidupan emosinya dengan inteligensi, menjaga keselarasan emosi, dan pengungkapannya melalui keterampilan kesadaran diri, pengendalian diri, motivasi diri, empati dan keterampilan sosial.

Kecerdasan emosional saat ini menjadi bahasan yang menarik dalam bidang manajamen sumber daya manusia. Robbins dan Judge ${ }^{13}$ mendefinisikan kecerdasan emosional adalah kemampuan seseorang

${ }^{9}$ Edison, Anwar dan Komariah. “Manajemen Sumber Daya Manusia. Edisi Pertama. Alfabeta, Bandung (2016)

${ }^{10}$ Dessler, Gary. “Manajemen Sumber Daya Manusia”, PT Indeks, Jakarta, (2010).

${ }^{11}$ Hasibuan, Malayu S.P. “Manajemen Sumber Daya manusia”. Edisi Revisi. Jakarta: Penerbit Salemba Empat, (2016)

${ }^{12}$ Goleman, Daniel. “Working With Emotional Intelligence terjemahan”. Gramedia Pustaka Utama, Jakarta. (2015)

${ }^{13}$ Robbins, S. P., \& Judge, T.A. “Organizational Behaviour”. Pearson. (2015) 
untuk menilai emosi dalam diri dan orang lain, memahami makna emosi-emosi, dan mengatur emosi seseorang secara teratur.

Sedangkan McShane dan Von Glinow dalam Wibowo ${ }^{14}$, mengartikan kecerdasan emosional sebagai sekumpulan kemampuan untuk merasakan dan menyatakan emosi, mengasimilasi emosi dalam berpikir, memahami dan menghubungkan emosi dalam diri sendiri dan orang lain. Daniel Goleman ${ }^{15}$, sendiri mengemukakan bukan hanya satu jenis kecerdasan yang monolitik penting untuk meraih sukses dalam kehidupan, melainkan ada spektrum kecerdasan yang lebar dengan dengan tujuan varietas utama yaitu linguistik, matematika/logika, spesial, kinestetik, musik, interpersonal dan intrapersonal dan disebut sebagai kecerdasan emosional.

\section{a. Dimensi dan Indikator Kecerdasan Emosional}

Kecerdasan emosional terbagi dalam beberapa aspek kemampuan yang membentuknya. Mneurut Goleman dalam Wibowo ${ }^{16}$, mengungkapkan lima indikator kecerdasan emosional: yang dapat menjadi pedoman bagi individu untuk mencapai kesuksesan, yaitu:

1) Kesadaran diri

- Mengenali emosi diri sendiri beserta efeknya

- Mengetahui kekuatan dan batas-batas diri sendiri

- Percaya dengan kemampuan diri dan keyakinan tentang harga diri

2) Mengelola emosi diri

- Kemampuan untuk mengelola emosi-emosi dan desakandesakan hati yang merusak

- Luwes terhadap perubahan (mudah beradaptasi) dan bertangung jawab atas kinerja pribadi

14 Wibowo. "Analisis Pengaruh Kecerdasan Emosional (EQ) dan Kecerdasan Intelektual (SQ) Pada Kinerja Karyawan”, (2015)

${ }^{15}$ Goleman, Daniel."Emotional Intelligence: Kecerdasan Emosional". Jakarta: PT Gramedia Pustaka Utama. (2016)

16 Wibowo. "Analisis Pengaruh Kecerdasan Emosional (EQ) dan Kecerdasan Intelektual (SQ) Pada Kinerja Karyawan”, (2015) 
- Mudah menerima dan terbuka terhadap gagasan, pendekatan dan informasi-informasi baru.

3) Memotivasi diri sendiri

- Mempunyai dorongan untuk berprestasi/tidak cepat puas.

- Memiliki kekuatan untuk berfikir positif dan optimis.

4) Mengenali emosi orang lain

- Mampu menerima sudut pandang dari orang lain.

- Peka terhadap perasaan orang lain.

5) Keterampilan sosial

- Dapat memberikan pesan dengan jelas dan meyakinkan orang lain.

- Dapat membangkitkan inspirasi kelompok dan orang lain.

- Berani memulai dan mengelola perubahan (katalisator perubahan).

- Mampu melakukan negoisasi dan pemecahan silang pendapat.

\section{Gaya Kepemimpinan Transformasional}

Menurut pendapat Robbins \& Judge ${ }^{17}$, dinyatakan bahwa kepemimpinan transformasional adalah pemimpin yang menginspirasi para pengikutnya untuk mengenyampingkan kepentingan pribadi mereka demi kebaikan organisasi dan mereka mampu memiliki pengaruh yang luar biasa pada diri para pengikutnya. Mereka menaruh perhatian terhadap kebutuhan pengembangan diri para pengikutnya, mengubah kesadaran para pengikut atas isu-isu yang ada dengan cara membantu orang lain memandang masalah lama dengan cara yang baru, serta mampu menyenangkan hati dan menginspirasi para pengikutnya untuk bekerja keras guna mencapai tujuan-tujuan bersama.

${ }^{17}$ Robbins, S. P., \& Judge, T.A. “Organizational Behaviour”. Pearson. (2015) 


\section{a. Dimensi dan Indikator Gaya Kepemimpinan Transformasional}

Bass dan Ruth dalam Wijonarko ${ }^{18}$, mengemukakan, terdapat empat karakteristik kepemimpinan transformasional, antara lain sebagi berikut:

1) Pengaruh Idealis (Individualized Influence).

- Pemimpin sebagai panutan

- Sikap hormat dari bawahan

- Pemimpin memberikan kepercayaan kepada bawahan

2) Motivasi Inspirasional (Inspirational Motivation).

- Inspirasi untuk menyelesaikan tugas

- Motivasi untuk menyelesaikan tugas dengan semangat

3) Stimulasi Intelektual (Intellectual Stimulation).

- Motivasi untuk inovatif

- Pemimpin mendorong bawahan untuk kreatif

4) Konsiderasi Individual (Individualized Consideration).

- Pertimbangan kebutuhan

- Pemberian perhatian

\section{Kinerja}

Menurut Mangkunegara ${ }^{19}$ pengertian kinerja (prestasi kerja) adalah hasil kerja secara kualitas dan kuantitas yang dicapai oleh seorang pegawai dalam melaksanakan tugasnya sesuai dengan tanggung jawab yang diberikan kepadanya.

${ }^{18}$ Wijonarko, R Widi Nugroho. "Pengaruh Gaya Kepemimpinan Transformasional dan Motivasi Kerja Terhadap Kinerja Agen (Studi Kasus Pada Agen PT. Asuransi Jiwasraya Persero Yogyakarta Kota Branch Office)". Yogyakarta: Universitas Negeri Yogyakarta. . (2014).

${ }^{19}$ Mangkunegara, Anwar Prabu.. “Sumber Daya Manusia Perusahaan”. Cetakan kedua belas. Remaja Rosdakarya, Bandung, (2015). 
a. Dimensi dan indikator kinerja

Dimensi dan Indikator kinerja menurut Wiratama dan Sintaasih ${ }^{20}$, adalah sebagai berikut :

1) Kualitas kerja

- Ketepatan dalam mengerjakan suatu tugas

- Ketelitian mengerjakan tugas dengan meminimalisir kesalahan

- keterampilan

2) Kuantitas kerja

- Kecepatan

3) Tanggung jawab

- Menerima dan melaksanakan pekerjaan dengan mengerjakan pekerjaan sebaik-baiknya

- Sarana dan prasarana

4) Kerja sama

- kekompakan dengan rekan kerja dengan saling berpartisipasi mengerjakan tugas

\section{Model Penelitian}

Menurut Sugiyono ${ }^{21}$ kerangka berfikir merupakan model konseptual tentang bagaimana teori berhubungan dengan berbagai faktor yang telah di identifikasi sebagai masalah yang penting. Berikut ini dapat digambarkan kerangka pemikiran yang dijadikan dasar pemikiran dalam penelitian ini. Kerangka tersebut merupakan dasar pemikiran dalam melakukan analisis pada penelitian ini.

${ }^{20}$ Wiratama, I. N. J. A., \& Sintaasih, D. K. "Pengaruh Kepemimpinan, Diklat, dan Disiplin Kerja Terhadap Kinerja Karyawan PDAM Tirta Mangutama Kabupaten Badung”. Matrik: Jurnal Manajemen, Strategi Bisnis dan Kewirausahaan. . (2013)

${ }^{21}$ Sugiyono. “Metode Penelitian Kuantitatif Kualitatif \& RND”, Alfabeta, Bandung, 
H3

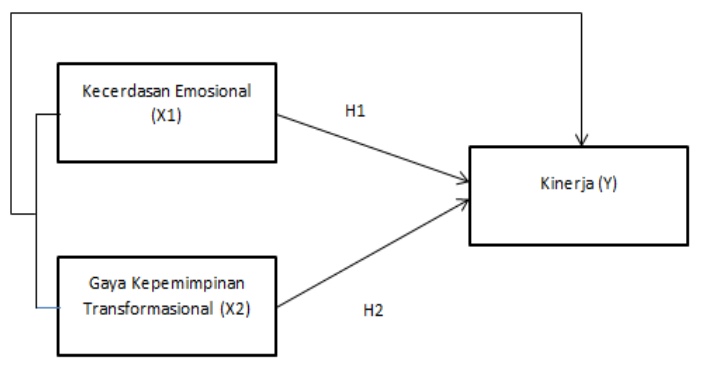

\section{METODE PENELITIAN}

\section{Populasi dan Sampel}

\section{1) Populasi}

Menurut Sugiyono ${ }^{22}$, populasi merupakan wilayah generalisasi yang terdiri atas obyek atau subyek yang mempunyai kualitas dan karakteristik tertentu yang ditetapkan oleh peneliti untuk dipelajari dan kemudian ditarik kesimpulannya. Populasi yang digunakan dalam penelitian ini adalah seluruh guru tetap yang berjumlah 177 guru.

\section{2) Sampel}

Menurut Sugiyono ${ }^{23}$, sampel merupakan bagian dari jumlah dan karakteristik yang dimiliki oleh populasi Penentuan jumlah sampel dari populasi menggunakan rumus Slovin

Keterangan:

$$
n=\frac{N}{1+N\left(e^{2}\right)}
$$

$\mathrm{n}$ : jumlah sampel

$\mathrm{N}$ : jumlah populasi

e: perkiraan tingkat kesalahan yaitu sebesar $5 \%$

${ }^{22}$ Sugiyono. “Statistika Untuk Penelitian”, Alfabeta, Bandung, (2017)

${ }^{23}$ Ibid 
Berdasarkan rumus yang telah dijelaskan, maka berikut ini adalah perhitungan sampel penelitian:

$$
\begin{gathered}
\mathrm{n}=\frac{177}{1+175 \cdot(0,05)^{2}} \\
\mathrm{n}=\frac{175}{1,4425}=122,70
\end{gathered}
$$

Atas perhitungan diatas, maka jumlah sampel yang diambil dalam penelitian ini adalah 122,70 guru atau dibulatkan menjadi 123 guru pada SMA negeri se-Kecamatan Kalideres.

Metode pengambilan sampel yang dilakukan dalam penelitian ini adalah probability sampling dengan menggunakan teknik Simple random sampling. Probability sampling adalah teknik pengambilan sampel yang memberikan peluang yang sama bagi setiap unsur (anggota) populasi untuk dipilih menjadi anggota sampel ${ }^{24}$. Teknik Simple random sampling digunakan teknik pengambilan anggota sampel dari populasi yang dilakukan secara $a \mathrm{cak}^{25}$.

\section{HASIL PENELITIAN DAN PEMBAHASAN}

\section{1) Uji Validitas dan Reliabilitas}

Berdasarkan pengujian validitas dan reliabilitas yang telah dilakukan, semua item pernyataan dinyatakan valid dan reliable

\section{2) Uji Normalitas}

Uji normalitas bertujuan untuk menguji apakah dalam sebuah model regresi, variabel pengganggu atau residual mempunyai distribusi normal atau tidak. Seperti diketahui bahwa nilai residual mengikuti distribusi normal. Kalau asumsi ini dilanggar maka uji statistik menjadi tidak valid untuk jumlah sampel kecil ${ }^{26}$.

${ }^{24}$ Sugiyono. “Statistika Untuk Penelitian”, Alfabeta, Bandung, (2017).

${ }^{25}$ Ibid

${ }^{26}$ Ghozali, Imam. “Aplikasi Analisis Multivariate Dengan Program IBM SPSS 25 (edisi kesembilan)”, Universitas Diponegoro, Semarang, (2018). 


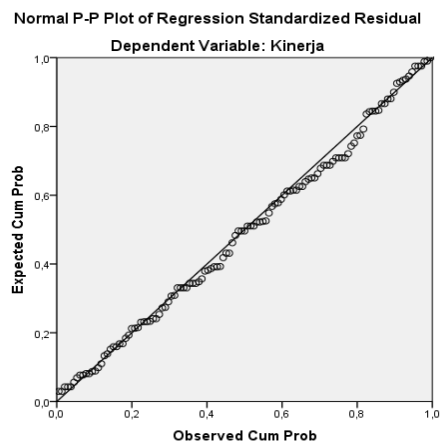

Berdasarkan gambar diatas bisa disimpulkan bahwa hubungan dari variabel kecerdasan emosional dan gaya kepemimpinan transformasional terhadap kinerja guru menunjukan suatu pola dengan distribusi yang normal. Distribusi yang normal ini terlihat dari data yang menyebar di sekitar garis diagonal.

One-Sample Kolmogorov-Smirnov Test

\begin{tabular}{|c|c|c|}
\hline & & $\begin{array}{c}\text { Unstandardized } \\
\text { Residual }\end{array}$ \\
\hline $\mathrm{N}$ & & 123 \\
\hline \multirow[t]{2}{*}{ Normal Parameters } & Mean &, 0000000 \\
\hline & Std. Deviation & 1,00430441 \\
\hline \multirow[t]{3}{*}{ Most Extreme Differences } & Absolute &, 062 \\
\hline & Positive &, 062 \\
\hline & Negative &,- 029 \\
\hline \multicolumn{2}{|l|}{ Test Statistic } &, 062 \\
\hline \multicolumn{2}{|l|}{ Asymp. Sig. (2-tailed) } & $200^{c, d}$ \\
\hline \multicolumn{3}{|c|}{$\begin{array}{l}\text { a. Test distribution is Normal. } \\
\text { b. Calculated from data. } \\
\text { c. Lilliefors Significance Correction. } \\
\text { d. This is a lower bound of the true significance. } \\
\text { Sumber : data primer yang telah diolah spss, } 2019\end{array}$} \\
\hline
\end{tabular}

Pada uji selanjutnya di tabel diatas yang dipergunakan adalah uji kolmogorov-smirnov,dari hasil uji tersebut menghasilkan output Asymp. Sig. (2-tailed) sebesar 0,200. Hasil tersebut lebih besar dari 
0,05 dan kurang dari 1, sehingga hal tersebut menunjukan bahwa data berdistribusi normal.

\section{3) Uji Multikolinearitas}

Pengujian multikolinearitas bertujuan untuk menguji apakah model regresi ditemukan adanya korelasi antar variabel bebas (independen). Pengujian multikolinearitas adalah pengujian yang mempunyai tujuan untuk menguji apakah dalam model regresi ditemukan adanya korelasi antara variabel independen ${ }^{27}$.

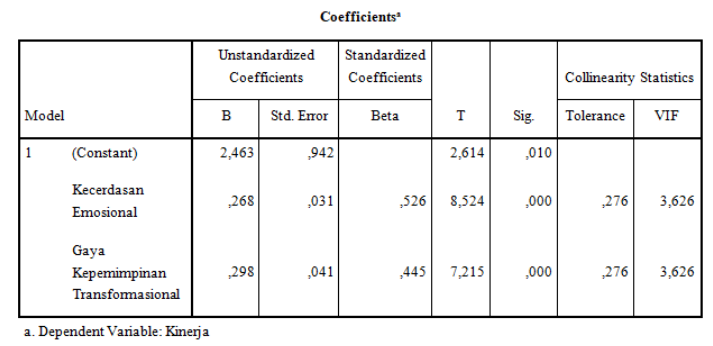

Pada tabel diatas menjelaskan bahwa data yang telah diujikan tidak mengalami gejala multikolinearitas dari setiap variabel independen yaitu dengan cara melihat hasil uji dari nilai tolerance dan VIF. Dari hasil uji tolerance menunjukan bahwa masing-masing variabel independen dari penelitian mempunyai nilai sebesar 0,276 dimana nilai lebih besar dari 0,10 dan nilai VIF sebesar 3,626 dimana nilai lebih kecil dari 10.

\section{4) Uji Heteroskedastisitas}

Uji Heterokedastisitas bertujuan untuk menguji apakah model regresi terjadi ketidaksamaan varian dari residual satu pengamatan ke pengamatan yang lain. Jika varian dan residual satu pengamatan ke pengamatan yang lain tetap, maka disebut homokedastisitas dan jika

${ }^{27}$ Ghozali, Imam. “Aplikasi Analisis Multivariate Dengan Program IBM SPSS 25 (edisi kesembilan)”, Universitas Diponegoro, Semarang, (2018). 
berbeda disebut heterokedastisitas. Cara mendeteksi heterokedastisitas adalah dengan melihat grafik plot antara nilai prediksi variabel dependen dengan residualnya dan melihat ada tidaknya pola tertentu pada grafik scatter plot $^{28}$.

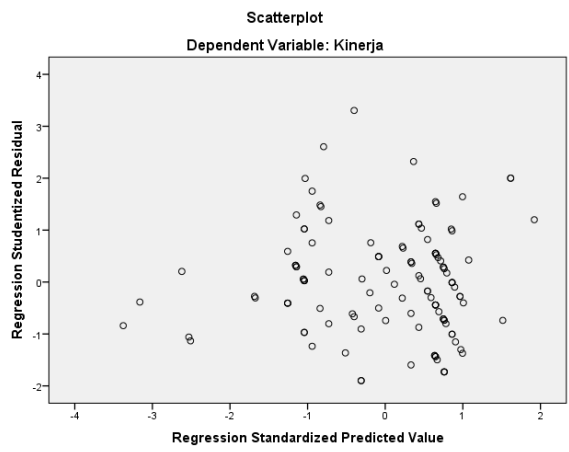

Berdasarkan gambar di atas, bisa dilihat pada scatterplott menunjukan bahwa titik-titik menyebar secara acak baik diatas maupun dibawah angka 0 (nol) pada sumbu Y, selain itu tidak terjadi suatu pola yang jelas pada penyebaran data yang telah diujikan. Hal tersebut menyimpulkan bahwa tidak terjadinya gejala heteroskedastisitas.

Selain itu, uji ada atau tidaknya heteroskedastisitas dapat dilakukan dengan cara Uji Glejser, dengan cara melihat nilai signifikansi apakah nilai tersebut lebih besar dari 0,05. Jika hal tersebut terjadi maka tidak terjadi gejala heteroskedastisitas.

${ }^{28}$ Ghozali, Imam. “Aplikasi Analisis Multivariate Dengan Program IBM SPSS 25 (edisi kesembilan)”, Universitas Diponegoro, Semarang, (2018). 
Coefficients ${ }^{2}$

\begin{tabular}{|l|r|r|r|r|r|}
\hline & \multicolumn{2}{|c|}{$\begin{array}{c}\text { Unstandardized } \\
\text { Coefficients }\end{array}$} & $\begin{array}{r}\text { Standardized } \\
\text { Coefficients }\end{array}$ & & \\
\cline { 2 - 5 } Model & B & \multicolumn{1}{|c|}{$\begin{array}{c}\text { Std. } \\
\text { Error }\end{array}$} & Beta & T & Sig. \\
\hline (Constant) &, 133 &, 572 & &, 233 &, 816 \\
Kecerdasan Emosional &, 022 &, 019 &, 195 & 1,132 &, 260 \\
$\begin{array}{l}\text { Gaya Kepemimpinan } \\
\text { Transformasional }\end{array}$ &,- 015 &, 025 &,- 106 &,- 613 &, 541 \\
\hline
\end{tabular}

Berdasarkan tabel diatas, maka didapat nilai signifikansi (sig.) dari variabel kecerdasan emosional sebesar 0,260 dan nilai signifikansi (sig.) dari variabel gaya kepemimpinan transformasional sebesar 0,514. Nilai signifikansi tersebut lebih besar dari 0,05. Hal tersebut menyimpulkan bahwa tidak terjadinya gejala heteroskedastisitas.

\section{5) Hasil Uji Hipotesis Penelitian}

\section{a) Uji t}

Uji t digunakan untuk menunjukkan seberapa jauh pengaruh satu variabel independen secara individual dalam menerangkan variabel dependen ${ }^{29}$.

Coefficients ${ }^{2}$

\begin{tabular}{|c|c|c|c|c|c|}
\hline \multirow[b]{2}{*}{ Model } & \multicolumn{2}{|c|}{$\begin{array}{l}\text { Unstandardized } \\
\text { Coefficients }\end{array}$} & \multirow{2}{*}{$\begin{array}{c}\begin{array}{c}\text { Standardized } \\
\text { Coefficients }\end{array} \\
\text { Beta }\end{array}$} & \multirow[b]{2}{*}{$\mathrm{T}$} & \multirow[b]{2}{*}{ Sig. } \\
\hline & B & Std. Error & & & \\
\hline (Constant) & 2,463 &, 942 & & 2,614 &, 010 \\
\hline Kecerdasan Emosional (X1) &, 268 &, 031 &, 526 & 8,524 &, 000 \\
\hline $\begin{array}{l}\text { Gaya Kepemimpinan } \\
\text { Transformasional }(\mathrm{X} 2)\end{array}$ &, 298 &, 041 & 445 & 7,215 &, 000 \\
\hline
\end{tabular}

Dari hasil uji diatas diperoleh $\mathrm{t}$ hitung untuk kecerdasan emosional sebesar 8,524 dan gaya kepemimpinan transformasional sebesar 7,215. Untuk menentukan $t$ tabel digunakan lampiran

${ }^{29}$ Ibid 
statistika tabel $\mathrm{t}$, dengan menggunakan $\alpha=5 \%$ dengan (df) $\mathrm{n}-1$ atau 123-1 = 22. Maka diperoleh t tabel 1,9796.

a. Pengaruh kecerdasan emosional terhadap kinerja guru

Terlihat bahwa $t$ hitung untuk koefisien kecerdasan emosional adalah 8,524 > t tabel 1,9796. Sehingga hipotesis dari penelitian ini yang berbunyi terdapat pengaruh yang signifikan antara kecerdasan emosional terhadap kinerja guru (Ha diterima dan Ho ditolak), jadi secara parsial terdapat pengaruh yang signifikan antara kecerdasan emosional terhadap kinerja guru.

b. Pengaruh gaya kepemimpinan transformasional terhadap kinerja guru.

Terlihat bahwa $\mathrm{t}$ hitung untuk koefisien gaya kepemimpinan transformasional adalah 7,215 > t tabel 1,9796. Sehingga hipotesis dari penelitian ini yang berbunyi terdapat pengaruh yang signifikan antara gaya kepemimpinan transformasional terhadap kinerja guru (Ha diterima dan Ho ditolak), jadi secara parsial terdapat pengaruh yang signifikan antara gaya kepemimpinan transformasional terhadap kinerja guru.

b) Uji f

Uji simultan $\mathrm{F}$ digunakan untuk mengetahui apakah ada pengaruh secara bersama-sama antara variabel-variabel independen (kecerdasan emosional dan gaya kepemimpinan transformasional) terhadap variabel dependen (kinerja guru) ${ }^{30}$.

${ }^{30}$ Ghozali, Imam. “Aplikasi Analisis Multivariate Dengan Program IBM SPSS 25 (edisi kesembilan)”, Universitas Diponegoro, Semarang, (2018). 
ANOVA

\begin{tabular}{|l|r|r|r|c|c|}
\hline Model & \multicolumn{1}{|c|}{$\begin{array}{c}\text { Sum of } \\
\text { Squares }\end{array}$} & Df & Mean Square & F & Sig. \\
\hline $1 \quad$ Regression & 853,094 & 2 & 426,547 & 415,966 &, $000^{\circ}$ \\
Residual & 123,053 & 120 & 1,025 & & \\
Total & 976,146 & 122 & & & \\
\hline
\end{tabular}
a. Dependent Variable: Kinerja (Y) Predictors: (Constant), Gaya Kepemimpinan Transformasional (X2), Kecerdasan
Emosional (X1)

Dari hasil uji f pada diatas diperoleh f hitung sebesar 415,966 sedangkan nilai $F$ tabel digunakan lampiran statistika tabel $F$. Menghitung $\mathrm{F}$ tabel dengan $\mathrm{dk}$ pembilang $=\mathrm{k}$ (jumlah variabel independen) dan dk penyebut $=(n-k-1)$ dengan taraf kesalahan $5 \%$. Dari rumus tersebut diperoleh $\mathrm{dk}$ pembilang $=\mathrm{k}$ dan $\mathrm{dk}$ penyebut $=(\mathrm{n}-$ k-1) dengan taraf kesalahan 0,05 atau 5\%. Dari rumus tersebut diperoleh $\mathrm{dk}$ pembilang $=2 \mathrm{dan} \mathrm{dk}$ penyebut $=123-2-1=120$. Maka diperoleh F tabel sebesar 3,07.

Hal tersebut menunjukan bahwa nilai $\mathrm{F}$ hitung $>\mathrm{F}$ tabel dengan nilai 415,966 > 3,07 maka Ho ditolak dan Ha diterima, artinya variabel kecerdasan emosional dan gaya kepemimpinan transformasional secara bersama-sama berpengaruh terhadap kinerja guru.

\section{6) Hasil Analisis Linier Berganda}

a) Hasil Uji Persamaan Regresi Linier Berganda

Tehnik analisis yang digunakan dalam penelitian ini adalah tehnik analisis regresi linier berganda. Penelitian ini menggunakan analisis regresi berganda karena ingin mengetahui bagaimana variabel independen $(\mathrm{X})$ dapat mempengaruhi variabel dependen $(\mathrm{Y})$ secara langsung. Model regresi berganda bertujuan untuk memprediksi besar variabel dependen dengan menggunakan data variabel independen yang sudah diketahui besarnya. 
Coefficients $^{2}$

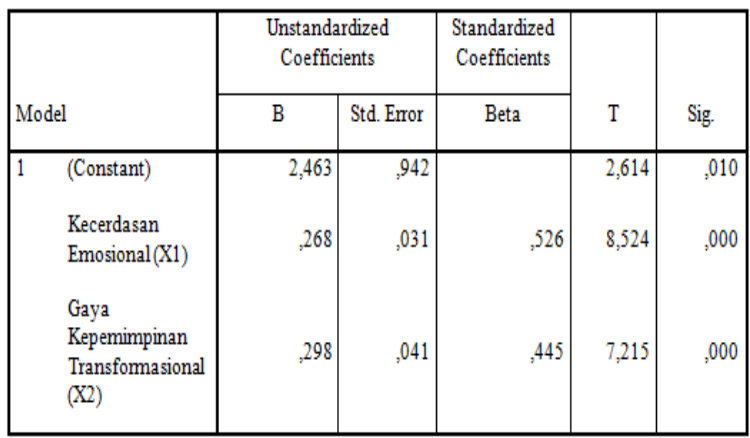

a. Dependent Variable: Kinerja $(\mathrm{Y})$

Dari hasil perhitungan tabel diatas, dapat disajikan ke dalam bentuk persamaan regresi standarized sebagai berikut :

$$
\begin{aligned}
& Y=a+\beta_{1} X_{1}+\beta_{2} X_{2}+e \\
& Y=2,463+0,268 X_{1}+0,268 X_{2}+e
\end{aligned}
$$

\section{Keterangan:}

$$
\begin{array}{ll}
\mathrm{Y}=\text { Kinerja } \\
\mathrm{a} & =\text { Konstanta } \\
\mathrm{X} 1 & =\text { Kecerdasan Emosional } \\
\mathrm{X} 2 & =\text { Gaya Kepemimpinan Transformasional } \\
\mathrm{b} 1 \mathrm{~b} 2 & =\text { Koefisien Regresi } \\
\mathrm{e} & =\text { Error }
\end{array}
$$

- Nilai konstanta (a) menunjukan bahwa besarnya dari nilai kinerja guru (Y). Variabel Kecerdasan emosional dan gaya kepemimpinan transformasional dinyatakan konstan dengan nilai kinerja guru sebesar 2,463

- Koefisien regresi variabel kecerdasan emosional (X1) sebesar 0,268 maka menyatakan bahwa adanya pengaruh antara kecerdasan emosional dengan kinerja guru, jika semakin baik kecerdasan emosional maka kinerja guru akan meningkat.

- Koefisien regresi variabel gaya kepemimpinan transformasional (X2) sebesar 0,268 maka menyatakan bahwa 
adanya pengaruh antara gaya kepemimpinan transformasional dengan kinerja guru, jika semakin baik gaya kepemimpinan transformasional maka kinerja guru akan meningkat.

\section{7) Hasil Uji Koefisiensi Determinasi (Adjusted $\mathrm{R}^{2}$ )}

Koefisien determinasi digunakan untuk mengukur sejauh mana kemampuan model dalam menerangkan variasi variabel dependen Nilai koefisien determinasi memiliki interval antara 0 sampai dengan 1. Nilai koefisien determinasi yang mendekati angka 1 merupakan model regresi yang baik karena hampir semua variabel yang dipakai mampu menerangkan variasi variabel dependen yang digunakan ${ }^{31}$.

Model Summary

\begin{tabular}{|l|r|r|r|r|}
\hline Model & \multicolumn{1}{|c|}{$R$} & R Square & \multicolumn{1}{c|}{$\begin{array}{c}\text { Adjusted } \mathrm{R} \\
\text { Square }\end{array}$} & \multicolumn{1}{c|}{ Std. Error of the Estimate } \\
\hline 1 &, $935^{\mathrm{a}}$ &, 874 &, 872 & 1,01264 \\
\hline
\end{tabular}

a. Predictors: (Constant), Gaya Kepemimpinan(X2), Kecerdasan Emosional(X1)

Berdasarkan tabel diatas, maka dapat disimpulkan bahwa koefisien determinasi yang sudah disesuaikan (Adjusted $\mathrm{R}$ Square) ialah sebesar 0,872 atau 87,2\%. Dari hal tersebut dapat disimpulkan bahwa semakin besar angka dari $\mathrm{R}$ square maka akan semakin kuat hubungan dari kedua variabel dalam model regresi. Maka 87,2\% variabel kinerja dapat dijelaskan oleh variabel kecerdasan emosional dan gaya kepemimpinan transformasional. Sedangkan sisanya, yaitu $12,8 \%$ lainnya dipengaruhi oleh variabel lain yang tidak masuk dalam penelitian ini.

\section{SIMPULAN}

Berdasarkan hasil penelitian yang menggunakan linear berganda dapat disimpulkan bahwa kecerdasan emosional dan gaya

${ }^{31}$ Ghozali, Imam. “Aplikasi Analisis Multivariate Dengan Program IBM SPSS 25 (edisi kesembilan)”, Universitas Diponegoro, Semarang, (2018). 
kepemimpinan transformasional berpengaruh signifikan kepada kinerja guru baik secara sendiri-sendiri maupun langsung.

Implikasi dari penelitian ini adalah bahwa sekolah harus mampu meningkatkan kinerja para gurunya dengan terus meningkatkan kemampuan kecerdasan emosional dan tetap menerapkan gaya kepemimpinan transformasional.

Tentu masih banyak keterbatasan-keterbatasan dalam penelitian ini dan diharapkan untuk peneltian selanjutnya dapat mengurangi keterbatsan-keterbatasan tersebut.

\section{DAFTAR PUSTAKA}

Abdullah,M. “Manajemen dan Evaluasi Kinerja Karyawan”. Aswaja Presindo, Yogyakarta. (2014)

Advani, A., \& Abbas, Z. "Impact of Transformational and Transactional Leadership Styles on Employees' Performance of Banking Sector in Pakistan ". Global Journal of Management and Business Research, (2015).

Ardiyansyah, Sulistyowati "Pengaruh Kompetensi dan Kecerdasan Emosional Terhadap Kinerja Pegawai”. (2018)

Athoillah, Anton. "Dasar-dasar Manajemen”, C.V Pustaka Setia, Bandung, (2010).

Bhuono, Agung Nugroho. "Strategi Jitu Memilih Metode Statistik Penelitian dengan SPSS”, Penerbit Andi, Yogyakarta, (2005).

Bohlander, George and Snell, Scott. "Principles of Human Resource. Management, 15th ed. Mason". South Western - Cengage Learning, OH, (2010).

Darsono dan Siswandoko, Tjatjuk. "Manajemen Sumber Daya Manusia Abad 21", Nusantara Consulting, Jakarta, (2011).

Dessler, Garry. “Manajemen sumber Daya Manusia”. Salemba Empat, Jakarta (2015) 
Dessler, Gary. “Manajemen Sumber Daya Manusia”, PT Indeks, Jakarta, (2010).

Edison, Anwar dan Komariah. “Manajemen Sumber Daya Manusia. Edisi Pertama. Alfabeta, Bandung (2016)

Edy, Sutrisno. “ Manajemen Sumber Daya Manusia”, Kencana Prenada Media Group, Jakarta. (2016)

Fuad, Mas’ud. “Survai Diagnosis Organisasional (Konsep dan Aplikasi). Badan Penerbit Universitas Diponegoro”, (2004).

Ghozali, Imam. "Aplikasi Analisis Multivariate Dengan Program IBM SPSS 25 (edisi kesembilan)”, Universitas Diponegoro, Semarang, (2018).

Goleman, Daniel. “Working With Emotional Intelligence terjemahan”. Gramedia Pustaka Utama, Jakarta. (2015)

Goleman, Daniel.”Emotional Intelligence: Kecerdasan Emosional” (Alih Bahasa: T. Hermaya). Jakarta: PT Gramedia Pustaka Utama. (2016)

Gomes, Faustino Cardoso. "Manajemen Sumber Daya Manusia”, Penerbit Andi, Yogyakarta, (2003).

Hasibuan, Malayu S.P. “Manajemen Sumber Daya manusia”. Edisi Revisi. Jakarta: Penerbit Salemba Empat, (2016)

Jaya, M. K., Mulyadi, D., \& Sulaeman, E. . "Pengaruh Kecerdasan Emosional Terhadap Kinerja Karyawan Pada Kantor Kementerian Agama Kabupaten Kerawang”. Jurnal Manajemen, (2012)

Kharis, Indra. "Pengaruh Gaya Kepemimpinan Transformasional Terhadap Kinerja Karyawan Dengan Motivasi kerja Sebagai Variabel Intervening (Studi Pada Karyawan Bank Jatim Cabang Malang)", (2015).

Mangkunegara, Anwar Prabu.. Sumber Daya Manusia Perusahaan. Cetakan kedua belas. Remaja Rosdakarya, Bandung, (2015). 
Mulyono, Anton. “Manajemen”. Mardika Group, Bandung. (2015)

Northouse, Peter G. “Kepemimpinan Teori dan Praktek. Edisi Keenam”. Jakarta: Indeks. (2013)

Pradhan,S., \& Pradhan, R. K. “An Empirical Investigation Of Relationship Introduction”. (2015)

Priyatmo, Cornelius. "Pengaruh Kepemimpinan Transformasional Terhadap Kinerja Karyawan Dengan Mediasi Kepuasan Kerja”. (2018).

Radha, B., \& Arepalli, B. S. "Impact of Emotional Intelligence on Performance of Employees at Manufacturing Organizations”. International Journal of Recent Technology and Engineering, 8(3), 570-572. (2019)

Robbins, S. P.,\& Judge, T.A. “Organizational Behaviour”. Pearson. (2015)

Subagio, Mochamad. "Pengaruh kecerdasan emosional, motivasi kerja, dan sikap kerja terhadap kinerja karyawan pada pt ithaca resources”. XIX(01), 101-120. (2015)

Sudarmanto. “Kinerja dan Pengembangan Kompetensi SDM”, Pustaka Pelajar, Yogyakarta, (2009).

Sudaryono. “Budaya \& Perilaku Organisasi”, Edisi Pertama : Lentera Ilmu Cendekia, Jakarta. (2014)

Sugiyono. "Metode Penelitian Kombinasi (Mix Methods)". Bandung: Alfabeta. (2015).

Sugiyono. “Metode Penelitian Kuantitatif Kualitatif \& RND”, Alfabeta, Bandung, (2013).

Sugiyono. “Statistika Untuk Penelitian”, Alfabeta, Bandung, (2017).

Sunyoto, Danang. "Manajemen Sumber Daya Manusia”. CAPS, Yogyakarta. (2012). 
Terry, George dan Leslie W. Rue. “Dasar-dasar Manajemen”, Cetakan kesebelas, PT Bumi Aksara, Jakarta. (2010).

Wibowo. “Analisis Pengaruh Kecerdasan Emosional (EQ) dan Kecerdasan Intelektual (SQ) Pada Kinerja Karyawan”, (2015)

Wibowo. “Manajemen Kinerja”, Rajawali Pers, Jakarta. (2013).

Widayati, C. “Pengaruh Kecerdasan Emosional, Tingkat Pendidikan Dan Karir Terhadap Kinerja Karyawan (Studi kasus pada Sales Marketing PT Astra International Daihatsu Cabang Tangerang)”. Jurnal Ekonomi., (2016).

Wijaya, Tony. “Metodologi Penelitian Ekonomi dan Bisnis”. Yogyakarta: Graha Ilmu. (2013).

Wijonarko, R Widi Nugroho. "Pengaruh Gaya Kepemimpinan Transformasional dan Motivasi Kerja Terhadap Kinerja Agen (Studi Kasus Pada Agen PT. Asuransi Jiwasraya Persero Yogyakarta Kota Branch Office)". Yogyakarta: Universitas Negeri Yogyakarta. . (2014).

Wiratama, I. N. J. A., \& Sintaasih, D. K. "Pengaruh Kepemimpinan, Diklat, dan Disiplin Kerja Terhadap Kinerja Karyawan PDAM Tirta Mangutama Kabupaten Badung”. Matrik: Jurnal Manajemen, Strategi Bisnis dan Kewirausahaan. . (2013)

Yukl, Gary A. "Leadership in Organizations”, 8th Edition, Pearson, State University of New York, Albany. (2013

\section{Internet:}

https://tirto.id/pendidikan,2017

https:/www.republika.co.id/berita/pendidikan, 